\title{
Primær myelofibrose - patogenese, diagnostikk og behandling
}

\begin{abstract}
BAKGRUNN Primær myelofibrose er en malign myeloproliferativ sykdom. Den karakteriseres av proliferasjon av megakaryocyttene i beinmargen, forstyrret cytokinproduksjon samt reaktiv fibrose som medfører beinmargssvikt. Hensikten med denne artikkelen er å gi en oppdatert fremstilling av patofysiologi, diagnostikk og behandling av sykdommen.
\end{abstract}

KUNNSKAPSGRUNNLAG Artikkelen bygger på egen erfaring og på utvalg av artikler identifisert gjennom mange års erfaring med behandlingen av pasienter med myelofibrose.

RESULTATER De sykdomsinitierende molekylære mekanismer er fortsatt uavklarte, men mutasjon i to gener (JAK2 og MPL) forkommer hos $70 \%$ av pasientene og medfører økt produksjon av hematopoetiske celler. Diagnosen baseres på kliniske funn, beinmarghistologi og molekylærbiologiske undersøkelser. Primær myelofibrose har et variert klinisk forløp. Leveutsiktene avhenger av flere faktorer og er sterkt redusert ved høyrisikosykdom. Allogen stamcelletransplantasjon er den eneste behandling med kurativt potensial, men kun et mindretall av pasientene er egnet. Dersom transplantasjon ikke er aktuelt, er behandlingen symptomrettet. JAK2-hemmere er nye medikamenter som motvirker cytokinproduksjon og celleproliferasjon. Ruxolitinib er den første godkjente JAK2-hemmeren og har vist effekt på symptomer og livskvalitet.

FORTOLKNING Medikamentell hemning av JAK2-genet og den tilhørende signalveien JAK-STAT er et fremskritt i behandlingen. Stamcelletransplantasjon er midlertid fortsatt den eneste mulige kurative behandlingen av myelofibrose.

Primær myelofibrose er en malign myeloproliferativ sykdom som kan vise seg med anemi, slapphet og magesmerter eller med konstitusjonelle symptomer som feber, svette, og vekttap. Sykdommen karakteriseres ved beinmargsproliferasjon av megakaryocyttene og granulocyttforstadiene, forstyrret cytokinproduksjon samt reaktiv fibrose som medfører beinmargssvikt og ekstramedullær hematopoese (1). Den har et varierende klinisk forløp og påvirker leveutsiktene (2).

Primær myelofibrose hører til gruppen myeloproliferative neoplasier som omfatter blant annet polycythemia vera og essensiell trombocytose. Disse beslektede sykdommene kan transformeres til myelofibrose og kalles da post-polycythemia vera eller post-essensiell trombocytose-myelofibrose. Ramme 1 viser Verdens helseorganisasjons klassifikasjon av myeloproliferative neoplasier (1).

Ved myeloproliferative neoplasier er det påvist mutasjoner $\mathrm{i}$ genet for Janus-kinase-2 (JAK2) (fig 1). Denne oppdagelsen har gjort diagnostikken sikrere og ført til utviklingen av nye medikamenter som hemmer JAK2-proteinet. Hensikten med artikkelen er å gi en oppdatert gjennomgang av patogenese, diagnostikk og behandling ved primær myelofibrose.

\section{Kunnskapsgrunnlag}

Artikkelen bygger på utvalg av relevante studier og oversiktsartikler identifisert gjennom mange års erfaring $\mathrm{i}$ behandlingen av pasienter med myelofibrose, inkludert bruk av den nylig registrerte JAK2-hemmeren ruxolitinib.

\section{Patogenese}

De sykdomsinitierende genmutasjonene ved primær myelofibrose er ukjente, men 50-60\% av pasientene har mutasjonen JAK2 V617F (3). Mutasjonen kan også påvises ved polycythemia vera (over 90\%) og essensiell trombocytose (ca. $60 \%$ ). Omtrent $10 \%$ av pasientene med primær myelofibrose har mutasjon i $M P L W 515 / L$-genet (myeloproliferativ leukemi virus onkogen/trombopoietin-reseptor) (3). Andre mutasjoner er sjeldnere, er ikke sykdomsspesifikke og brukes ikke rutinemessig i diagnostikken (4). JAK2- og MPL-mutasjoner gir økt signalering via JAK-STAT-signalveien (STAT = signaltransduser og aktivator av transkripsjon), se figur 1 (4). Dette fører til myeloproliferasjon og en sekundær inflammasjon som medfører forstyrret cytokinproduksjon, inkludert frisetting av vekstfaktorer som stimulerer fibroblastene og medfører lokal fibrose og senere osteosklerose og beinmargssvikt som sluttresultat. Dette kalles primær beinmargsfibrose fordi den utløses av en primær malign beinmargssykdom; dette er i motsetning til sekundær beinmargsfibrose som utløses av medikamenter som trombopoietinreseptoragonister (5), autoimmune sykdommer eller maligniteter (6).

\section{Waleed Ghanima}

waleed.ghanima@so-hf.no

Hematologisk seksjon

Medisinsk avdeling

Sykehuset Østfold

og

Institutt for klinisk medisin

Oslo universitetssykehus

\section{Håvar Knutsen}

Hematologisk avdeling

Oslo universitetssykehus, Rikshospitalet

\section{Jan Delabie}

Avdeling for patologi

Oslo universitetssykehus, Radiumhospitalet

og

Institutt for klinisk medisin

Universitetet i Oslo

\section{Øystein Bruserud}

Hematologisk seksjon

Medisinsk avdeling

Haukeland universitetssykehus

og

Institutt for Indremedisin

Universitetet i Bergen

Se også kunnskapsprøve

på www.tidsskriftet.no/quiz

e-fig 4 finnes i Tidsskriftets elektroniske utgaver

\section{HOVEDBUDSKAP}

Primær myelofibrose er en myeloproliferativ malign sykdom

Mutasjon i to veldefinerte gener forekommer hos $70 \%$ av pasientene

Den eneste mulige kurative behandlingen er allogen stamcelletransplantasjon

JAK2-hemmere er en ny gruppe legemidler som kan redusere splenomegali og konstitusjonelle symptomer, forbedre livskvaliteten og muligens forlenge levetiden 


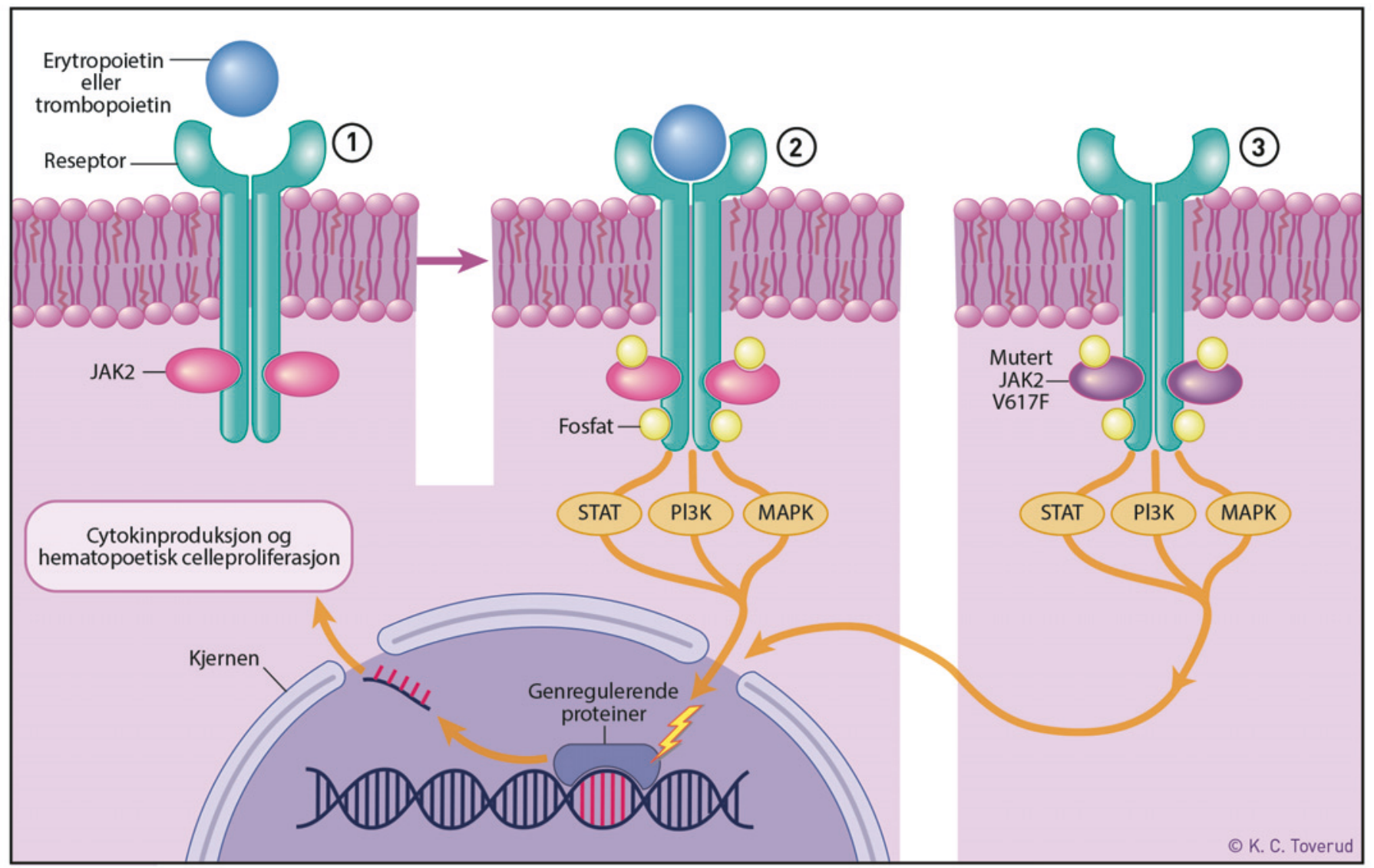

Figur 1 JAK2 er en intracytoplasmatisk ikke-reseptor tyrosinkinase. 1)Inaktiv villtype JAK2-reseptor på overflaten av de hematopoetiske cellene blir stimulert når erytropoietin eller trombopoietin binder seg til den (2). Aktivering av reseptoren fører til konformasjonsendring av denne og binding av fosfat (P) og aktivering av den intracytoplasmatiske delen av reseptoren med påfølgende aktivering av diverse signalveier som STAT (signaltransduser og aktivator av transkripsjon), PI3K (phosphatidylinositol 3-kinase) og MAPK (mitogenaktivert proteinkinase) som fører til celleproduksjon og differensiering. I celler med mutert JAK2 (3) pågår det en konstant signalering av signalveier og dermed økt produksjon av hematopoietiske celler

\section{Diagnose og utredning}

Insidensen av primær myelofibrose er angitt til 0,3-1,5 per 100 000/år (7, 8). I Norge er insidensen 0,4 per 100000 (9). Diagnosen stilles i henhold til WHOs 2008-kriterier for primær myelofibrose og baseres på kliniske funn, beinmarghistologi og molekylærbiologiske undersøkelser, se ramme 2 (1). Det kan iblant være vanskelig å skille primær myelofibrose fra andre tilstander som er ledsaget av beinmargsfibrose, særskilt ved fravær av mutasjon, som $\mathrm{f}$. eks. andre hematologiske neoplasier (andre myeloproliferative sykdommer eller myelodysplastisk syndrom) eller metastaserende neoplasier i beinmargen, som prostatakreft.

Median alder ved diagnosetidspunktet er 65-70 år og kjønnsfordelingen er lik. Det kliniske forløpet av primær myelofibrose er svært varierende. Hos noen er det en indolent sykdom med lang overlevelse, hos andre en aggressiv symptomgivende sykdom med kort overlevelse. Primær myelofibrose kan være asymptomatisk og fanges opp ved rutineprøver som viser lett anemi, trombocytose og/eller leukocytose. Vanlige symptomer og funn ved symptomatisk sykdom er anemi, slapphet, hepatosplenomegali med abdominale smerter, metthetsfølelse eller konstitusjonelle symptomer (feber, svette, og vekttap) (3). Ekstramedullær hematopoese kan forekomme hos $10 \%$, og symptomene avhenger av lokalisasjonen (10). Symptomatisk sykdom ses ofte ved det fibrotiske stadiet av primær myelofibrose, i motsetning til det tidlige prefibrotiske stadiet, som utgjør ca. $30 \%$ av tilfellene.

Utredningen starter med perifere blodtellinger, blodutstryk og biokjemiske prøver. Anisopoikilocytose, mikrocytær/normocytær anemi, dacryocytter (dråpeformede), schistocytter (fragmenter), erytroblaster og myeloblaster kan ses i utstryket (fig 2), men utstryket kan også være normalt i tidlige stadier. Forhøyet laktatdehydrogenase (LDH) ses ofte og indikerer ineffektiv hematopoese og hemolyse (10).

\section{Beinmargshistologi}

Beinmargsbiopsi er helt sentral for å stille diagnosen primær myelofibrose (fig 3), siden histologiske forandringer utgjør et av hovedkriteriene for diagnosen. Megakaryocyttproliferasjon og atypi samt økt bindevev (fibrose), som hovedsakelig består av kollagen type III (også kalt retikulin) og kollagen type I-fibre i beinmargen er de mest typiske forandringene. Fibrosen graderes i fire gra-

\section{RAMME 1}

Verdens Helseorganisasjons klassifikasjon av myeloproliferative neoplasier (1)

Kronisk myelogen leukemi (KML)

Kronisk nøytrofil leukemi

Polycythemia vera

Primær myelofibrose

\section{Essensiell trombocytemi}

Kronisk eosinofil leukemi

\section{Mastocytose}

Ikke klassifiserbare myeloproliferative neoplasier 


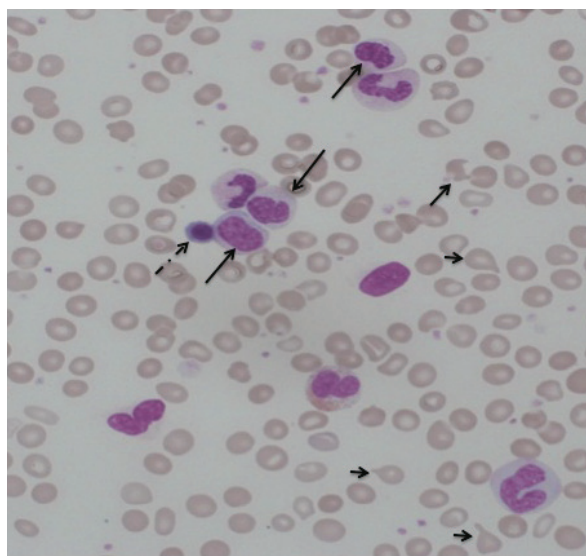

Figur 2 Typisk blodbilde ved primær myelofibrose med anisopoikilocytose og dråpeformede erytrocytter (kort pil), og leukoerytroblastose med umodne myelogene celler (lang pil), erytroblaster (stiplet pil) og schistocytter (fragmenter) (mellomstor pil)

der fra MF-0 til MF-3 (11). Ved prefibrotisk stadium av primær myelofibrose ser man enten ingen fibrose (MF-0) eller liten fibrose (MF-1). Større mengder av tykkere og kryssende fibre av kollagen type III og ofte kollagen type I ses ved det fibrotiske stadiet. Prefibrotisk primær myelofibrose er en ny klassifisering og representerer en diagnostisk utfordring fordi det ofte kan være vanskelig å skille den fra essensiell trombocytose $(12,13)$. Prefibrotisk primær myelofibrose progredierer i betydelig større grad til fibrotisk primær myelofibrose enn det es-

\section{RAMME 2}

Verdens helseorganisasjons kriterier for diagnose av primær myelofibrose. Diagnosen krever tilstedeværelse av alle hovedkriterier og minst to bikriterier (1)

\section{Hovedkriterier}

1 Megakaryocyttproliferasjon og atypi ${ }^{1}$ vanligvis ledsaget av retikulin og/eller kollagenfibrose i beinmarg

2 Fravær av polycythemia vera, kronisk myelogen leukemi, myelodysplastisk syndrom eller andre myeloide neoplasier

3 JAK2-V617F-mutasjon eller annen klonal markør, f.eks. MPL W515K/L, eller fravær av reaktiv fibrose i beinmargen

\section{Bikriterier}

1 Leukoerytroblastose

$2 \varnothing$ kning i serum-laktatdehydrogenase

3 Anemi

4 Splenomegali

1 Små til store megakaryocytter med forstyrret kjerne-cytoplasma-ratio, hyperkromasi, bulløs eller irregulær lobulering og ansamling (clusteringl sensiell trombocytose gjør og har signifikant kortere overlevelse (14).

\section{Cytogenetisk analyse}

Cyotogenetisk analyse, såkalt karyotyping, anbefales gjennomført hos alle yngre pasienter. Karyotyping har diagnostisk (for å utelukke kronisk myelogen leukemi), prognostisk og behandlingsmessig betydning. Cytogenetisk analyse utføres på beinmargsaspirat. Cytogenetiske avvik kan forekomme hos $30 \%$.

\section{Molekylærbiologiske undersøkelser}

JAK2-mutasjonen utgjør et diagnostisk hovedkriterium (1). Prøven tas på perifert blod. MPL W515K/L-mutasjon bør gjøres dersom JAK2 er negativ (15). BCR-ABLanalyse skal gjøres for å utelukke kronisk myelogen leukemi. Andre mutasjonsanalyser utføres ikke rutinemessig.

\section{Overlevelse og prognostiske faktorer}

Primær myelofibrose har et svært variert klinisk forløp. Median overlevelse er ca. fem år, men kan variere fra ett år til > 30 år. Hyppigste dødsårsaker er transformasjon til akutt leukemi, progresjon av primær myelofibrose, trombose, portal hypertensjon og blødninger, kardiovaskulære komplikasjoner og infeksjoner (16). Myeloproliferative sykdommer er hyppigste enkeltårsak til abdominal trombose (17).

Det er etablert prognostiske skåringssystemer, dels for vurdering av forventet overlevelse fra diagnosetidspunkt (IPSS (16)), dels for vurdering av risiko under sykdomsforløpet (DIPSS (18) og DIPSS pluss (19)). DIPSS er mest anvendt (tab 1).

\section{Behandlingsmål og behandlingsmuligheter}

Primær myelofibrose håndteres hovedsakelig av spesialister i blodsykdommer ved område- eller lokalsykehus og i samarbeid med universitetssykehusene. Behandlingsmålet må kartlegges før start av behandling. Målet med behandlingen er å øke overlevelsen ved å hindre beinmargssvikt og transformasjon til akutt leukemi, og å behandle symptomer som anemi, konstitusjonelle symptomer, symptomgivende hepatosplenomegali og ekstramedullær hematopoese samt hindre trombohemoragiske komplikasjoner $(10,20)$. Den eneste dokumentert livsforlengende og mulig kurative behandlingen er allogen stamcelletransplantasjon. Det er viktig ved diagnosetidspunktet å ta stilling til om pasienten kan være kandidat for dette, og den vurderingen må fortløpende gjøres under oppfølgingen av pasienten. Når denne behandlingsmuligheten ikke foreligger, er behandlingen symptomrettet.

Valg av behandling baseres på risikostra- tifisering. Ubehandlet observasjon er aktuelt hos asymptomatiske pasienter med lav risiko og intermediær risiko 1 . Dersom behandling er nødvendig pga. trombocytose, kan alternativene være interferon, hydroksyurea eller anagrelid. Pasienter med intermediær risiko 2 eller høy risiko har relativt kort forventet overlevelse (tab 1), har vanligvis symptomer og er dermed behandlingstrengende. Disse pasientene skal vurderes med tanke på allogen stamcelletransplantasjon når de er under 60-65 år. De som ikke egner seg for transplantasjon pga. manglende donor, komorbiditet eller alder, kan tilbys symptomrettet behandling, se behandlingsalgoritme (fig 4). For en mer detaljert oversikt over behandlingen, se nordiske retningslinjer for diagnose og behandling av myeloproliferative neoplasier (20).

\section{Kurativ allogen \\ stamcelletransplantasjon}

Allogen stamcelletransplantasjon er den eneste behandlingen med kurativt potensial, men på grunn av mortalitetsrisikoen som er knyttet til selve transplantasjonen er dette bare aktuelt hos yngre pasienter med kort forventet levetid ( $<3-5$ år), dvs. gruppen klassifisert med høy risiko eller intermediær risiko 2 (4, 10, 21). Allogen stamcelletransplantasjon kan utføres enten med fullintensitetskondisjonering, også kalt myeloablativ kondisjonering, dvs. å gi store mengder cellegift for å oppnå fullstendig utrydning av beinmargscellene, eller med doseredusert kondisjonering som gir lavere kortsiktig toksisitet (21) og muliggjør allogen stamcelletransplantasjon opp mot 60-65 års alder. 3-5 års overlevelse er rapportert å være $30-70 \%$ etter fullintensitetskondisjonering og 45-85\% etter doseredusert kondisjonering (21). Det finnes ingen kontrollerte studier der man har sammenliknet respons og overlevelse for de to transplantasjonsformene. Generelt foretrekkes det fortsatt full intensitet for yngre pasienter (opp mot 40-45 år) og doseredusert for eldre pasienter $(4,21)$.

\section{Symptomrettet behandling med ikke-målrettede midler}

Behandling av anemi

Anemi er det vanligste funnet ved primær myelofibrose. Den skal behandles når den er symptomgivende, og blodtransfusjoner er standardbehandlingen (10). Gjentatte transfusjoner medfører jernakkumulering og er som førstevalg mest aktuell for eldre pasienter med kort leveutsikt. Erytropoietin (f.eks. $150-300 \mu \mathrm{g}$ darbepoietin- $\alpha$ subkutant ukentlig) kan forsøkes hos pasienter med moderat anemi og lavt serum-erytropoietin $(<125 \mathrm{U} / \mathrm{l})$, særlig hvis det ikke foreligger vesentlig splenomegali. Om lag 50\% responderer på behandlingen (22). 


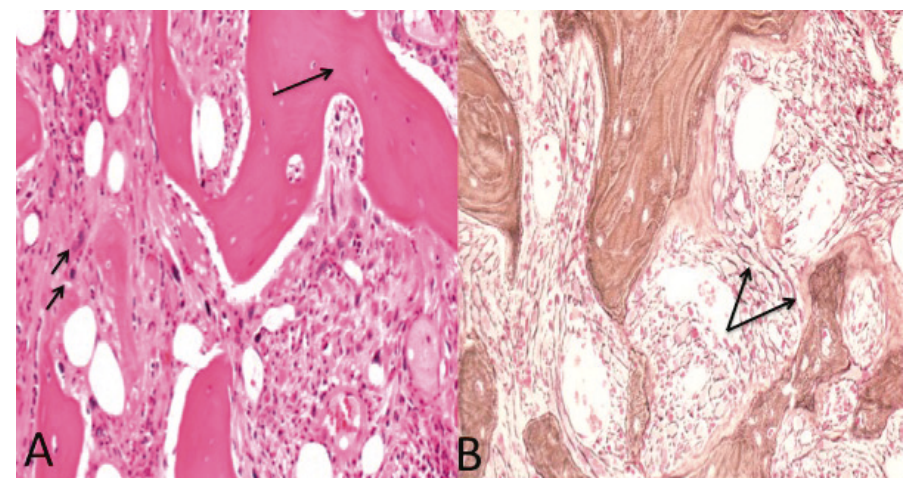

Figur 3 al Primær myelofibrose med osteosklerose (lang pill og megakryocyttansamling (kort pil) (hematoksylin-og eosinfarget, X200); b) Primær myelofibrose med fibrose grad MF-3; snittet er Gomori-farget for påvisning av kollagen type-III (retikulin)-fibre (lange piler)

Andre medikamenter som danazol og talidomid kan ha effekt på anemien. Effekten kan forbedres ved kombinasjon med prednisolon. Danazol $200 \mathrm{mg}$ daglig med gradvis doseøkning til $600 \mathrm{mg}$ daglig, kan gi forbigående transfusjonsuavhengighet hos $35 \%$ (23). Talidomid (50-100 mg daglig) kan redusere anemi og splenomegali (24); opptil $60 \%$ kan få økning i hemoglobinkonsentrasjonen ved kombinasjon med prednisolon $(0,5 \mathrm{mg} / \mathrm{kg} / \mathrm{dag}$, deretter nedtrapping) (25). Lenalidomid og pomalidomid (uregistrert) er talidomidderivater som også har vist god effekt på anemien, men med mindre bivirkninger som nevrotoksisitet (26). Effekten av alle disse medikamentene er imidlertid kortvarig, og de er ikke undersøkt i sammenliknende studier.

\section{Behandling av trombocytose}

Trombocytose forekommer ofte i den tidlige fasen av primær myelofibrose, særskilt ved prefibrotisk primær myelofibrose. Ettersom det er vanskelig å skille prefibrotisk primær myelofibrose fra essensiell trombocytose,

Tabell 1 DIPSS - prognostisk skåringssystem for primær myelofibrose (18). Skåren kan anvendes under hele sykdomsforløpet for å estimere overlevelsen. Median overlevelse ved lavrisiko (summert risikoskår 0) = > 240 måneder, intermediær risiko 1 (sum mert risikoskår 1-2) = 170 måneder, intermediær risiko 2 (summert risikoskår 3-4) = 48 måneder og høyrisiko (summert risikoskår 5-6) = 18 måneder

\begin{tabular}{lc} 
Prognostiske faktorer & Risikoskår \\
Alder $>65$ år & 1 \\
Anemi $(\mathrm{Hb}<10 \mathrm{~g} / \mathrm{dl})$ & 2 \\
Leukocytter $>25 \times 10^{9}$ & 1 \\
Blaster i blod $\geq 1 \%$ & 1 \\
Konstitusjonelle symptomer & 1 \\
\hline
\end{tabular}

anbefales det å behandle disse på samme vis. Aktuelle medikamenter er interferon- $\alpha$, hydroksyurea eller anagrelid samt acetylsalisylsyre $(4,20)$.

Hydroksyurea er myelosuppressivt og reduserer leukocyttall og trombocyttall og foretrekkes for pasienter $>60$ år. Nøye oppfølging av perifere blodverdier er nødvendig, siden hydroksyurea kan gi leukotrombopeni. Interferon- $\alpha$ er immunmodulerende og har cytoreduktiv effekt. Interferon- $\alpha$ er det eneste medikamentet som har vist en viss effekt på fibroseutviklingen i beinmarg (27). Pegylerte interferoner er førstevalg til pasienter $<60$ år som trenger cytoreduktiv behandling.

\section{Splenomegali og konstitusjonelle symptomer}

Hydroksyurea regnes som førstelinjevalg for pasienter med symptomgivende splenomegali (4). Medikamentet kan redusere miltstørrelsen og konstitusjonelle symptomer (28). Splenektomi kan være et alternativ for pasienter med symptomgivende splenomegali som ikke responderer på medikamentell behandling. Om lag 50\% av pasientene kan bli transfusjonsuavhengige og noen kan bli kvitt konstitusjonelle symptomer (4). Effekten av splenektomi og hydroksyurea er imidlertid kortvarig. Splenektomi er et alternativ, men er forbundet med en høy operativ mortalitet (7-9\%) og morbiditet $(30 \%)(29,30)$.

\section{JAK2-hemmere - en ny målrettet behandling}

JAK2-hemmere er den mest sykdomsspesifikke behandlingen ved myelofibrose. Disse medikamentene er tyrosinkinasehemmere som hemmer JAK2 -signalveien og dermed reduserer cytokinproduksjon og celleproliferasjon. Denne signalveien er viktig i hematopoetiske celler uavhengig av om JAK2genet er mutert eller ikke. JAK2-hemmere virker derfor både hos pasienter med og uten JAK2-mutasjon.
Ruxolitinib (Jakavi) er en JAK1- og JAK2-hemmer og er den første JAK-hemmeren som har fullført fase 3-studiene. Medikamentet er nå blitt godkjent for behandling av sykdomsrelatert splenomegali eller andre symptomer hos voksne pasienter med primær myelofibrose eller sekundær myelofibrose (post-polycythemia vera eller essensiell trombocytemi). I de to fase 3-studiene COMFORT-1 og -2 ble effekten og sikkerheten av ruxolitinib sammenliknet med henholdsvis placebo og beste behandlingsalternativ $(31,32)$. Ruxolitinib ga signifikant reduksjon av miltstørrelsen (minst 35\% reduksjon av miltvolum) hos $30-40 \%$ av pasientene etter 24-48 uker, mot $<1 \%$ i kontrollgruppen. Man så også bedring av konstitusjonelle symptomer sammenliknet med kontrollpersonene. I begge studier førte ruxolitinib til signifikant bedring i livskvaliteten. Begge studiene indikerer bedre overlevelse med ruxolitinib. Medikamentet ser ikke ut til å stanse eller reversere utviklingen av fibrose i beinmargen. Trombocytopeni og anemi er de hyppigste hematologiske bivirkningene, mens hodepine og svimmelhet var de hyppigste ikke-hematologiske bivirkningene. Det er flere JAK2-hemmere under utvikling og testing i kliniske studier. Foreløpige resultater tyder på en god del variasjon i virkningsmekanismene, effekt og bivirkningsprofil ved de forskjellige preparatene.

\section{Konklusjon}

Primær myelofibrose er en myeloproliferativ neoplastisk sykdom med variert klinisk forløp. Sykdommen reduserer levetiden og livskvaliteten. Allogen stamcelletransplantasjon er den eneste mulige kurative behandlingen. JAK2hemmere er nye og lovende medikamenter som kan redusere splenomegali og konstitusjonelle symptomer, forbedre livskvaliteten og muligens forlenge levetiden ved myelofibrose.

\section{Waleed Ghanima (f. 1964)}

er spesialist i blodsykdommer, overlege og førsteamanuensis.

Forfatter har fylt ut ICMJE-skjemaet og oppgir følgende interessekonflikter: Han har mottatt forskningsstipend og honorarer for foredrag og skrivning av kongressrapport fra Novartis som produserer ruxolitinib.

\section{Håvar Knutsen (f. 1947)}

er spesialist i blodsykdommer, overlege og medforfatter av det nordiske handlingsprogrammet for myeloproliferative sykdommer. Forfatter har fylt ut ICMJE-skjemaet og oppgir følgende interessekonflikter: Han har mottatt foredragshonorar og fått dekket reisekostnader til internasjonale kongresser fra Novartis. 


\section{Jan Delabie (f. 1961)}

er spesialist i hematopatologi, overlege og professor II.

Forfatter har fylt ut ICMJE-skjemaet og oppgir ingen interessekonflikter.

\section{Øystein Bruserud (f. 1955)}

er spesialist i blodsykdommer, seksjonsoverlege og professor.

Forfatter har fylt ut ICMJE-skjemaet og oppgir ingen interessekonflikter.

\section{Litteratur}

1. Tefferi A, Vardiman JW. Classification and diagnosis of myeloproliferative neoplasms: the 2008 World Health Organization criteria and point-ofcare diagnostic algorithms. Leukemia 2008; 22: $14-22$.

2. James C, Ugo V, Le Couédic JP et al. A unique clonal JAK2 mutation leading to constitutive signalling causes polycythaemia vera. Nature 2005; 434: 1144-8.

3. Tefferi A, Vainchenker W. Myeloproliferative neoplasms: molecular pathophysiology, essential clinical understanding, and treatment strategies. J Clin Oncol 2011; 29: 573-82.

4. Tefferi A. How I treat myelofibrosis. Blood 2011 117: 3494-504.

5. Ghanima W, Junker P. Hasselbalch $\mathrm{HC}$ et al. Fibroproliferative activity in patients with immune thrombocytopenia (ITP) treated with thrombopoietic agents. Br J Haematol 2011; 155: 248-55.

6. Kuter DJ, Bain B, Mufti $G$ et al. Bone marrow fibrosis: pathophysiology and clinical significance of increased bone marrow stromal fibres. $\mathrm{Br} \mathrm{J}$ Haematol 2007; 139: 351-62.

7. Mesa RA, Silverstein MN, Jacobsen SJ et al. Population-based incidence and survival figures in essential thrombocythemia and agnogenic myeloid metaplasia: an Olmsted County Study 1976-1995. Am J Hematol 1999; 61: 10-5

8. Johansson P, Kutti J, Andréasson B et al. Trends in the incidence of chronic Philadelphia chromosome negative (Ph-) myeloproliferative disorders in the city of Göteborg, Sweden, during 1983-99. J Intern Med 2004; 256: 161-5

9. Kreftregisteret. http://www.kreftregisteret.no/no/ (25.6.2013)
10. Barbui T, Barosi G, Birgegard G et al. Philadelphia-negative classical myeloproliferative neoplasms: critical concepts and management recommendations from European LeukemiaNet. J Clin Oncol 2011; 29: $761-70$.

11. Thiele J, Kvasnicka HM, Facchetti F et al. European consensus on grading bone marrow fibrosis and assessment of cellularity. Haematologica 2005; 90: 1128-32.

12. Wilkins BS, Erber WN, Bareford D et al. Bone marrow pathology in essential thrombocythemia: interobserver reliability and utility for identifying disease subtypes. Blood 2008; 111: 60-70.

13. Thiele J, Kvasnicka HM, Zankovich R et al. Clinical and morphological criteria for the diagnosis of prefibrotic idiopathic (primaryl myelofibrosis. Ann Hematol 2001: 80: 160-5

14. Barbui T, Thiele J, Passamonti F et al. Survival and disease progression in essential thrombocythemia are significantly influenced by accurate morphologic diagnosis: an international study. J Clin Oncol 2011; 29: 3179-84.

15. Pardanani AD, Levine RL, Lasho T et al. MPL515 mutations in myeloproliferative and other myeloid disorders: a study of 1182 patients. Blood 2006; 108: $3472-6$.

16. Cervantes F, Dupriez B, Pereira A et al. New prognostic scoring system for primary myelofibrosis based on a study of the International Working Group for Myelofibrosis Research and Treatment. Blood 2009; 113: 2895-901.

17. Kiladjian JJ, Cervantes F, Leebeek FW et al. The impact of JAK2 and MPL mutations on diagnosis and prognosis of splanchnic vein thrombosis: a report on 241 cases. Blood 2008; 111: 4922-9.

18. Passamonti F, Cervantes F, Vannucchi AM et al. A dynamic prognostic model to predict survival in primary myelofibrosis: a study by the IWG-MRT International Working Group for Myeloproliferative Neoplasms Research and Treatment). Blood 2010; 115: 1703-8.

19. Gangat N, Caramazza D, Vaidya R et al. DIPSS plus: a refined Dynamic International Prognostic Scoring System for primary myelofibrosis that incorporates prognostic information from karyotype, platelet count, and transfusion status. J Clin Oncol 2011; 29: 392-7

20. Nordic guidelines on the diagnosis and treatment of patients with myelproliferative neoplasms 2013 http://www.nmpn.org/index.shtml (25.6.2013).

21. McLornan DP, Mead AJ, Jackson G et al. Allogeneic stem cell transplantation for myelofibrosis in 2012. Br J Haematol 2012; 157: 413-25.

22. Huang J, Tefferi A. Erythropoiesis stimulating agents have limited therapeutic activity in transfusion-dependent patients with primary myelofibrosis regardless of serum erythropoietin level. Eur J Haematol 2009; 83: 154-5.

23. Cervantes F, Alvarez-Larrán A, Domingo A et al. Efficacy and tolerability of danazol as a treatment for the anaemia of myelofibrosis with myeloid metaplasia: long-term results in 30 patients. $\mathrm{Br} J$ Haematol 2005; 129: 771-5.

24. Marchetti M, Barosi G, Balestri F et al. Low-dose thalidomide ameliorates cytopenias and splenomegaly in myelofibrosis with myeloid metaplasia: a phase II trial. J Clin Oncol 2004; 22: 424-31.

25. Mesa RA, Steensma DP. Pardanani A et al. A phase 2 trial of combination low-dose thalidomide and prednisone for the treatment of myelofibrosis with myeloid metaplasia. Blood 2003; 101: 2534-41.

26. Mesa RA, Yao X, Cripe LD et al. Lenalidomide and prednisone for myelofibrosis: Eastern Cooperative Oncology Group (ECOG) phase 2 trial E4903. Blood 2010; 116: 4436-8.

27. Silver RT, Vandris K, Goldman JJ. Recombinant interferon-? may retard progression of early primary myelofibrosis: a preliminary report. Blood 2011: 117: 6669-72.

28. Martínez-Trillos A, Gaya A, Maffioli M et al. Efficacy and tolerability of hydroxyurea in the treatment of the hyperproliferative manifestations of myelofibrosis: results in 40 patients. Ann Hematol 2010; 89: $1233-7$

29. Tefferi A, Mesa RA, Nagorney DM et al. Splenectomy in myelofibrosis with myeloid metaplasia: a single-institution experience with 223 patients. Blood 2000: 95: 2226-33.

30. Mesa RA, Nagorney DS, Schwager S et al. Palliative goals, patient selection, and perioperative platelet management: outcomes and lessons from 3 decades of splenectomy for myelofibrosis with myeloid metaplasia at the Mayo Clinic. Cancer 2006; 107: $361-70$.

31. Verstovsek S, Mesa RA, Gotlib J et al. A doubleblind, placebo-controlled trial of ruxolitinib for myelofibrosis. N Engl J Med 2012; 366: 799-807.

32. Harrison C, Kiladjian JJ, Al-Ali HK et al. JAK inhibition with ruxolitinib versus best available therapy for myelofibrosis. N Engl J Med 2012; 366: 787-98.

Mottatt 27.9. 2012, første revisjon innsendt 1.2. 2013, godkjent 25.6. 2013. Redaktør Sigurd Høye. 